\title{
NEW RESULTS OF STUDIES ON THE FOSSILS IN THE LOWER CAMBRIAN SEDIMENT DEPOSIT OF THE SÖDERFJÄRDEN BASIN
}

\author{
RISTO TYNNI
}

\begin{abstract}
TYNNI, RISTO 1982: New results of studies on the fossils in the Lower Cambrian sediment deposit of the Söderfjärden. Bull. Geol. Soc. Finland 54, 1-2, 57-68.

Fossils Mickwitzia monilifera and olenellid trilobite fragments are found in the greenish grey shale in the lower sediment formation of Söderfjärden at a depth of 237.8 and $278.05 \mathrm{~m}$. Microfossils (acritarchs) Archaeodiscina umbonulata, Baltisphaeridium cerinium, Granomarginata squamacea, Lophosphaeridium tentativum, Tasmanites bobrowskii, T. piritaensis were also observed in the lower part of the Söderfjärden sedimentary formation. In this lower intersection the microfossil genera resemble those in the upper sediment formation. Only one new species, Dictyotidium bottnicum, is described in the lower portion of the formation.

The occurrence of the fossils and microfossils in the Söderfjärden sediment formation suggest Lower Cambrian sedimentation.

Risto Tynni, Geological Survey of Finland, Kivimiehentie 1, SF-02150 Espoo 15, Finland.
\end{abstract}

\section{Introduction}

The subject of the description of the sediment deposit of Söderfjärden (Lauren et al. 1978) were the fossils and microfossils found at a depth of 73.6 to $139.55 \mathrm{~m}$ in hole No. 3 drilled by Paraisten Kalkki Oy. On the basis of its fossils this portion was interpreted as Lower Cambrian. The most important guide fossils and microfossils on which the dating was based were Volborthella tenuis and Tasmanites. Since seismic sounding suggested that the sedimentary deposit might be markedly thicker than the portion intersected by the drill hole, the fossils and dates of the underlying deposit have still to be established.
Drilling started again in 1979 under the supervision of Jyrki Lehtovaara. The whole sedimentary sequence close to drill hole No. 3 was intersected at a depth of 74.35 to 318.08 . Three sites showing fossil imprints or shell fragments were revealed.

\section{Fossils}

The drill core showed the imprint of a worm at a depth of $178 \mathrm{~m}$. At $237.8 \mathrm{~m}$ a few shell fragments of Mickwitzia (monilifera Lns) and at 278.05 two fragments, probably of trilobite, were observed. Both fossils, the brachiopoda Mickwitzia and the trilobite, have an important bearing on the dating and 

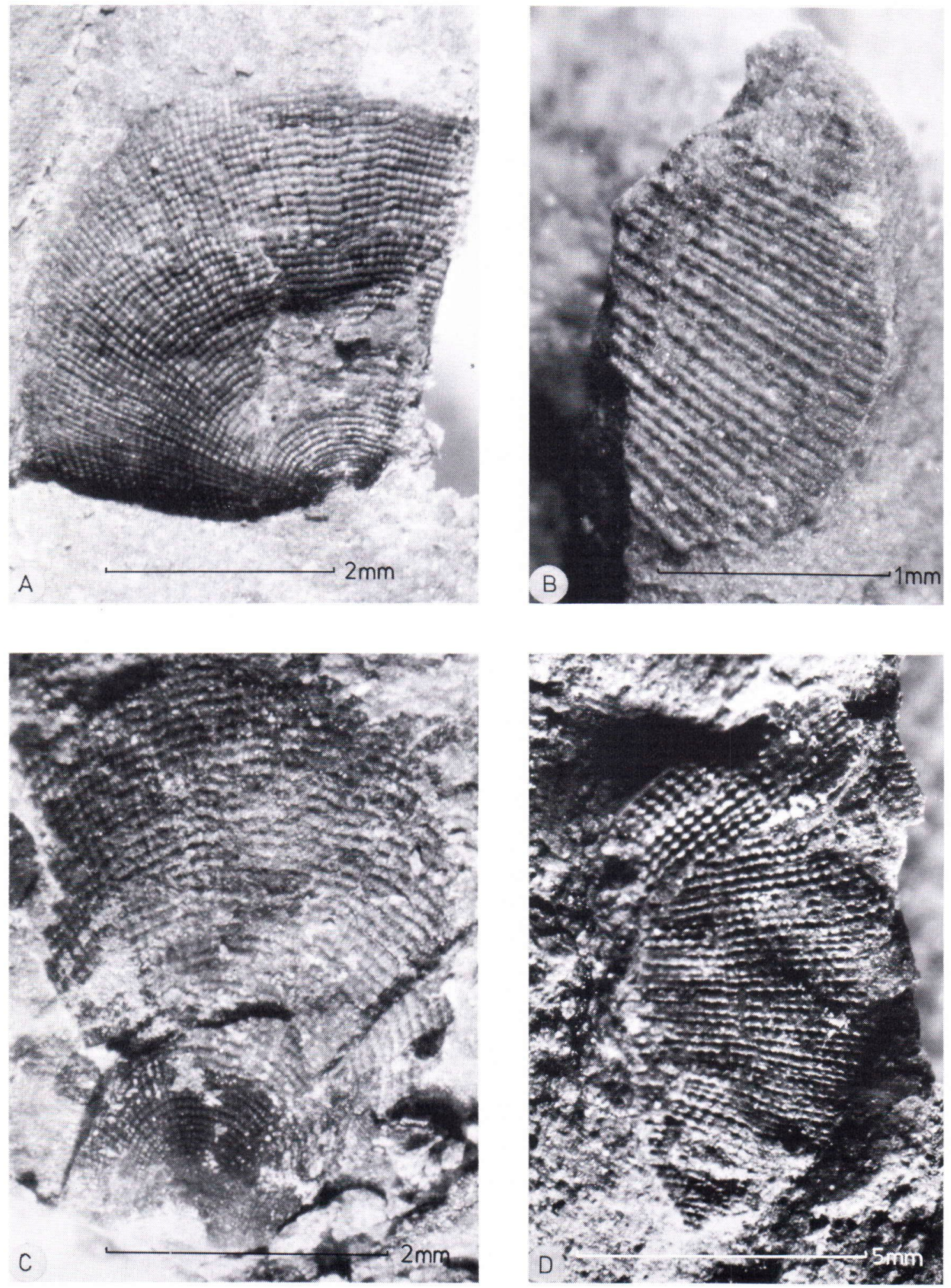
will be discussed in detail in the present context.

Mickwitzia monilifera Linnarsson has a characteristic surface structure that had allowed Wiman (1903) to identify the species in the fragmentary occurrences collected by G. von Schmalenséer in the Alland islands. The structure typical of Mickwitzia monilifera was a fairly dense nodular ruling. The surface of the fragments is occasionally folded perpendicular to the nodular ruling (Wiman op.cit.). The dense nodular ruling shows up clearly in the Söderfjärden occurrence (Fig. 1). Moreover the surface of the fragment exhibits undulatory folding, which is, however, oriented diagonally to the nodular ruling. The sedimentary rock of the occurrence is a greenish grey shale.

Mickwitzia fossils or Mickwitzia sandstones are encountered in many places in the Baltic area. They have been reported by Wiman (op.cit.) on the basis of boulders from the following sites in Aland: South Lumparn; Slemmern, east of Marianhamn; Ytternäset, in Marianhamn; and Granboda, in Lemland. In Sweden they have been found in the Närke area (Westergård 1940), Kinnekulla (Holm 1901, Högbom and Ahlström 1924), Biludden (Wiman 1903), and in the drilling at File Haidar in Gotland below the Mobergella and Volborthella occurrences $(5 \mathrm{~m})$ close to the upper portion of the Lower Cambrian deposit (Thorslund and Westergård 1938, Martinsson 1974). In Östergotland Mickwitzia monilifera has been identified in local erratics but not in situ (Martinsson op.cit.). In Dalsland it has been reported from a clastic dyke west of Lake Väner (Gavelin 1909). The most important site of comparison for the Söderfjärden Mickwitzia occurrence may be Finngrundet, where Mickwitzia was encountered in a drill core from Lower Cambrian bed. Volborthella also occurs in Finngrundet, at a depth of $82.22 \mathrm{~m}$ (Thorslund \& Axberg 1979). A similar sequence, Volborthella at $119 \mathrm{~m}$ and Mickwitzia at $237.8 \mathrm{~m}$, has been noted at Söderfjärden.

In Estonia Mickwitzia monilifera is associated with Schmidtiellus mickwitzi trilobite and Volborthella tenuis cephalopod in the Lükati formation (Mens and Pirrus 1977). According to Öpik (1956), the occurrence of Mickwitzia is confined to the Lükati formation and the upper portion of the Lontova formation. In southern Lithuania, Mickwitzia cf. monilifera has been encountered in some cores drilled into the Pirita formations, i.e. in rocks of the final stage of the Lower Cambrian (Korkutis, Lapinskas, Lashkov 1972).

The trilobite fragments found at Söderfjärden in the greenish grey shale at a depth of $278.05 \mathrm{~m}$ (Fig. 2 and 3) probably correspond to the olenellid trilobite, i.e. the oldest types in the Baltic area. Fig. 2 bears a marked resemblance to the Olenellus sp. fragment, Schalenskulptur von gewöhnlichem Aussehen, reported by Wiman (1903, Pl. 1, Fig. 6). The material described by Wiman derives mainly from the Gävle Bay, although he also has an observation on Olenellus sp. from Rosenberg in Aland (Wiman op.cit.). This may, however, be another genus resembling Olenellus. The surface structure of the Olenellus? curvicornis described by Poulsen (1932) from the Lower Cambrian formation in Ella Island, Greenland, is similar to that encountered in the Söderfjärden occurrence.

The trilobite Schmidtiellus mickwitzi (Moberg 1892) and the brachiopod Mickwitzia monilifera occur in Västergötland, Närke and Estonia in conglomerates that formed during the Lower Cambrian transgression (Martinsson 1974). In the Mjøsa area, Schmidtiellus cf. mickwitzi is encountered in the Brenn-

Fig. 1. Mickwitzia monilifera, shell fragments from a depth of $237.8 \mathrm{~m}$ in shale. Photo Kalevi Hokkanen $(\mathrm{A}-\mathrm{C})$ and Erkki Halme (D). 


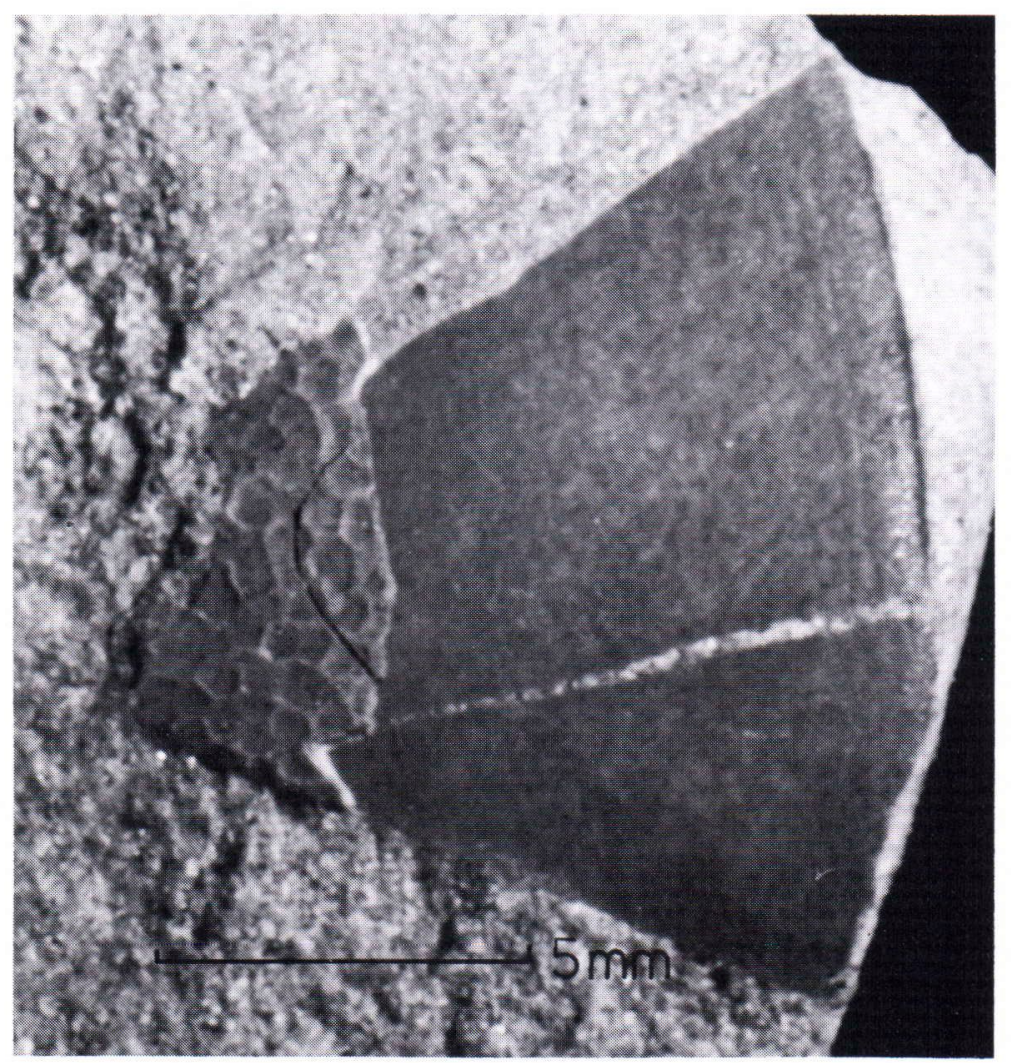

Fig. 2. Fragmentary cephalon of olenellid trilobite from a depth of $278.05 \mathrm{~m}$ in shale. A lateral border furrow visible at the right-hand margin. Photo $\mathrm{K}$. Hokkanen. saeter limestone above the Precambrian (Skjeseth 1963, Martinsson op.cit.). In the Mjøsa area, however, the olenellid trilobite Callavia sp. occurs together with Volborthella tenuis in the Bråstad shale, which is younger than the Brennsaeter limestone. With its stripes (Fig. 3), the fossil fragment from Söderfjärden resembles the surface structure of the rear of the head of the trilobite Strenuaeva sp. (Ahlberg 1979) and also the structures of the pleural areas of some other trilobites (cf. Dean and Martin 1978, p. 33).

Since fossils are sometimes associated with phosphorite nodules, attention was focused on the sedimentary rock of Söderfjärden at a depth of $314.55 \mathrm{~m}$, where there is a layer of a conglomeratic sandstone, less than $10 \mathrm{~cm}$ thick, with phosphorite nodules (Figs 4 and 5 ). The layer is very similar to that described by Thorslund and Axberg (1979) from the Lower Cambrian Västra Banken formation at a depth of 133.26 to $133.35 \mathrm{~m}$. At Söderfjärden the conglomeratic sandstone contains small amounts of glauconite as well. A larger individual phosphorite nodule was detected in the Söderfjärden formation above the olenellid trilobite at a depth of $277 \mathrm{~m}$. These phosphorites are free from fossils. Lehtovaara had earlier found what may be the remnant of a fossil in a phosphorite-bearing polymictic conglomerate in the upper part of the Söderfjärden sedimentary formation (Laurén et al. 1978, p. 25).

\section{Microfossils (acritarchs)}

The main objects of our attention are the microfossils in the lower sediment formation of Söderfjärden at a depth of 140.0 to $317.75 \mathrm{~m}$. 
New results of studies on the fossils in the Lower Cambrian sediment...

Fig. 3. A shell fragment of trilobite from a depth of $278.05 \mathrm{~m}$ Probably a remnant of the same individual as that shown in Fig. 2.

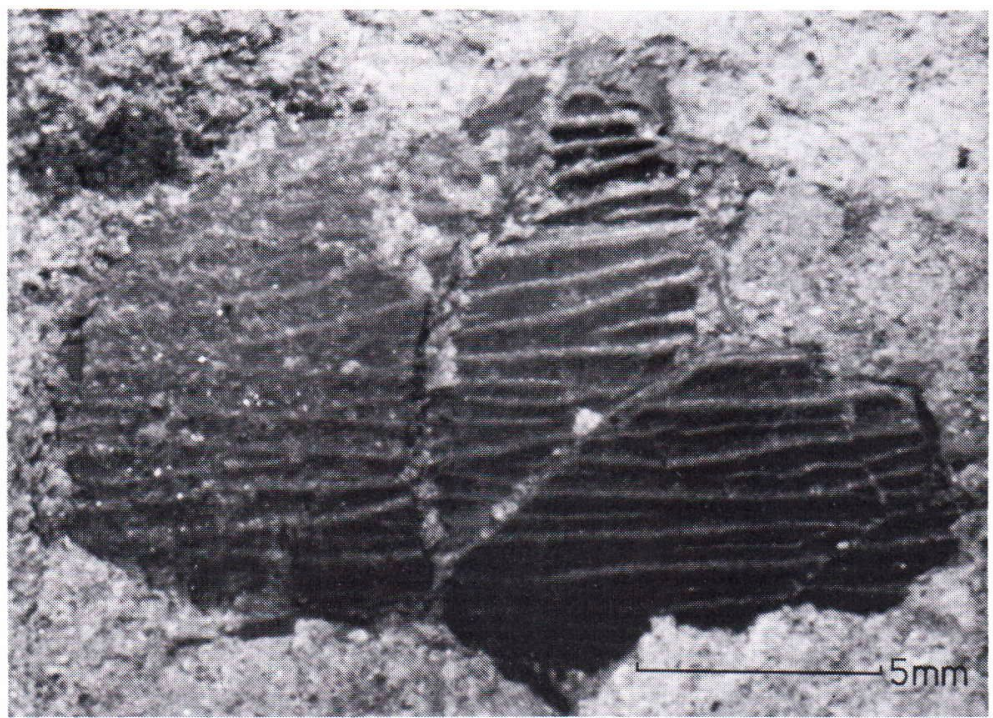

Fig. 4. Conglomeratic sandstone from a depth of $314.55 \mathrm{~m}$.

Fig. 5. A detail of conglomeratic sandstone. Small rounded phosphorite nodules in thin section.
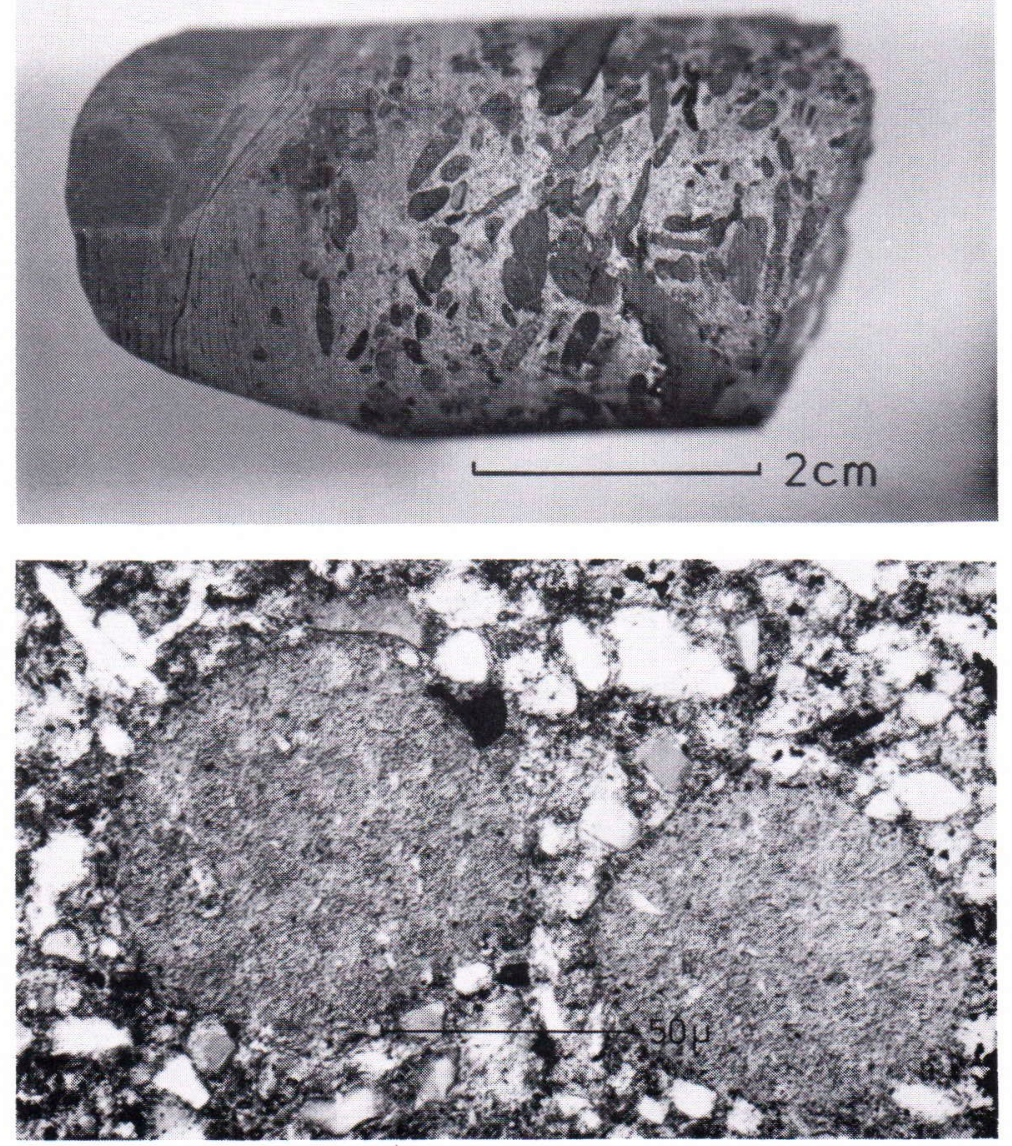


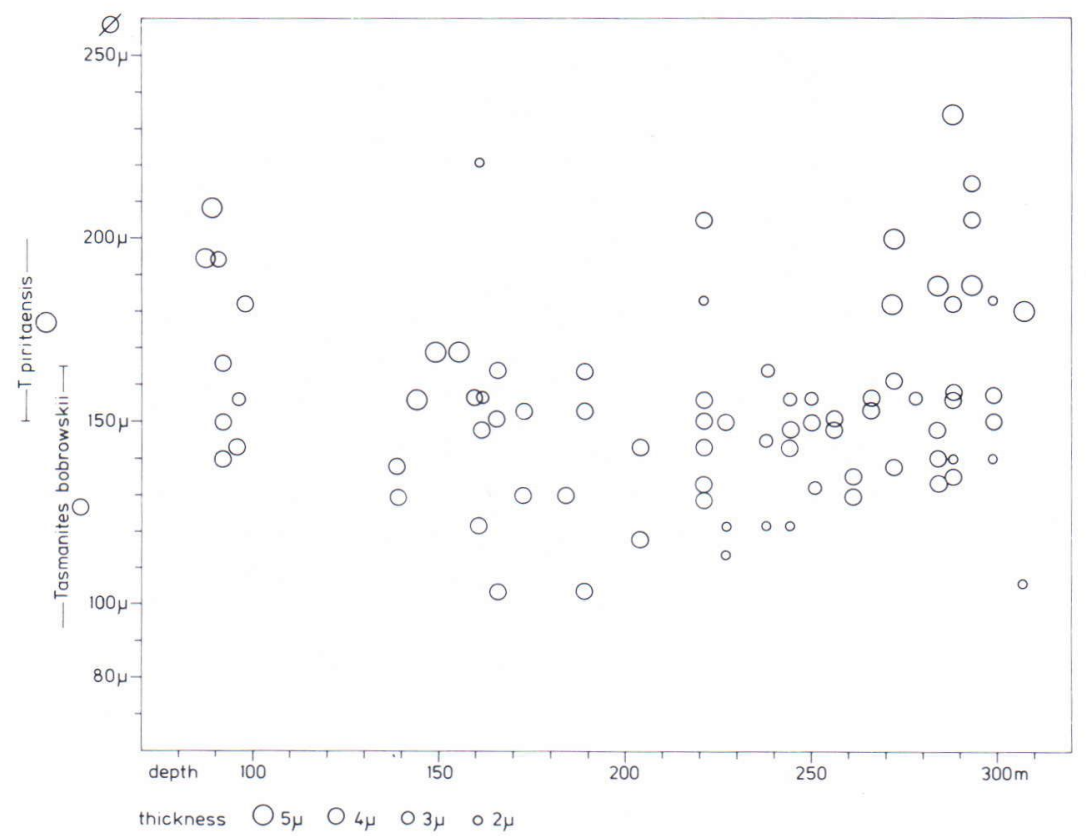

Fig. 6. Diameter and thickness of the shell of the Tasmanites from the Söderfjärdén sediment formation.
New microfossil analyses were performed on 35 sites at an average interval of $5 \mathrm{~m}$. In this lower intersection the microfossil genera resemble those in the upper sediment formation. The number of genera in the lower formation is, however, smaller than in the upper formation. Thus, the Cymatiosphaera genus, whose proportion is almost $40 \%$ at a depth of $129 \mathrm{~m}$, is practically lacking from the sedimentary formation at a depth of 140.0 to $317.75 \mathrm{~m}$.

The genus Granomarginata is very rare in the lower portion. Tasmanites bobrowskii (Wazynska 1967) and piritaensis (Posti et Jankauskas, 1976) are very common at depths of 89.2 and $92.3 \mathrm{~m}$ (about $36 \%$ ). Deeper down their proportion is low. Nevertheless, species T. bobrowskii in particular occurs at a depth of 139.5 to $261.1 \mathrm{~m}$ almost uninterruptedly, whereas the piritaensis type with a thicker shell is lacking from the greatest part of the deposit: it has been recorded at depths of 150 , 272.2 and $307.05 \mathrm{~m}$. Fig. 6 shows the most important parameters of the Tasmanites in the Söderfjärden sedimentary formation, i.e. the diameter and the thickness of the shell in graphic presentation. The third important quantity, the spacing between the pores, is 3 to $5 \mu$ for the majority of the species. As shown by the figure, most of the occurrences of Tasmanites bobrowskii fall within the size range of 90 to $160 \mu$ (the upper limit $130 \mu$, which I reported previously, should read $160 \mu$, Tynni 1978).

Table 1 lists the acritarch genera in the middle and lower portions of the Söderfjärden sediment formation and whose existence has been confirmed by checking. The fairly large Dictyotidium species is the most important new species found in the lower portion of the formation.

Dictyotidium bottnicum n.sp. (Figs. $7 \mathrm{~A}-\mathrm{G}$, $8 \mathrm{G})$

A spherical or oval vesicle, 70 to $112 \mu$ in diameter. The surface structure consists of slightly elevated polygonal ridges. The polygons vary in shape from trigonal to polygonal. They also vary in size. The pattern may be absent from the central parts in some individuals. They are sepia in colour, the smaller 
Table 1. Acritarch occurrences in the middle and lower parts of the Söderfjärden sediment formation.

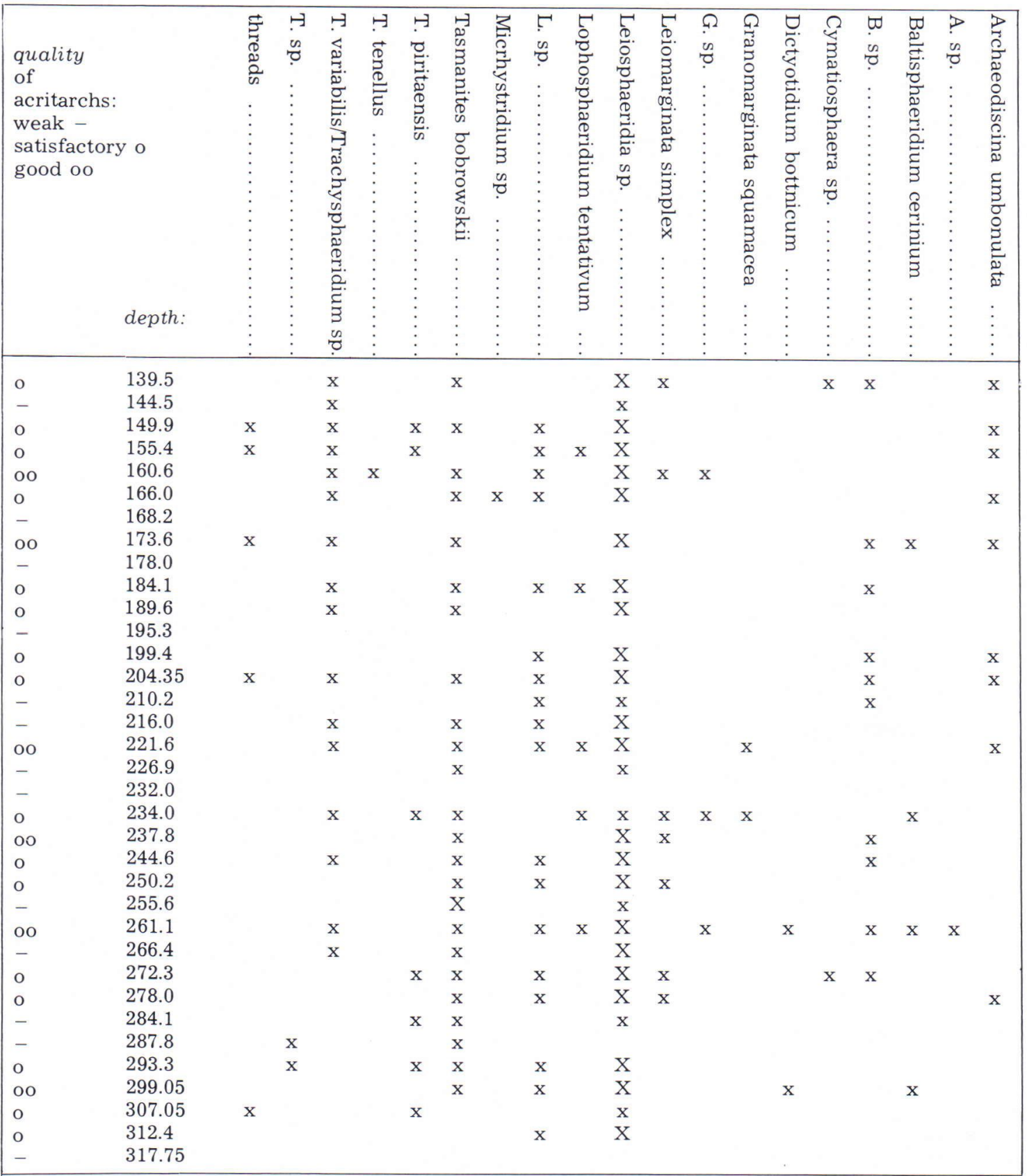

$\mathrm{x}=$ present, $\mathrm{X}=$ dominant

individuals being darker than the larger ones. The large individuals are occasionally raptured.
D. bottnicum has been encountered in about ten occurrences at depths of 261.1 and $299.05 \mathrm{~m}$. 

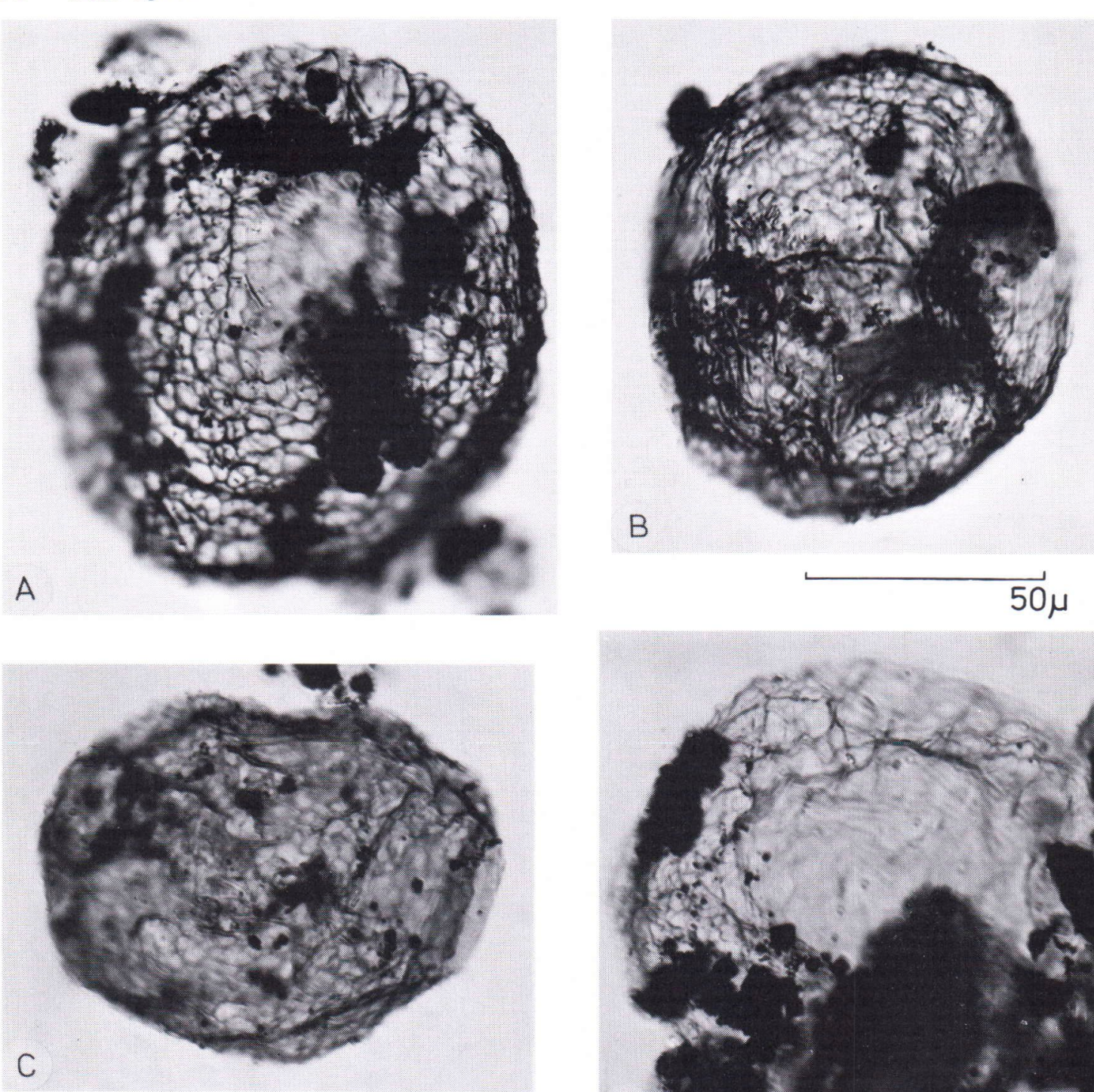

A
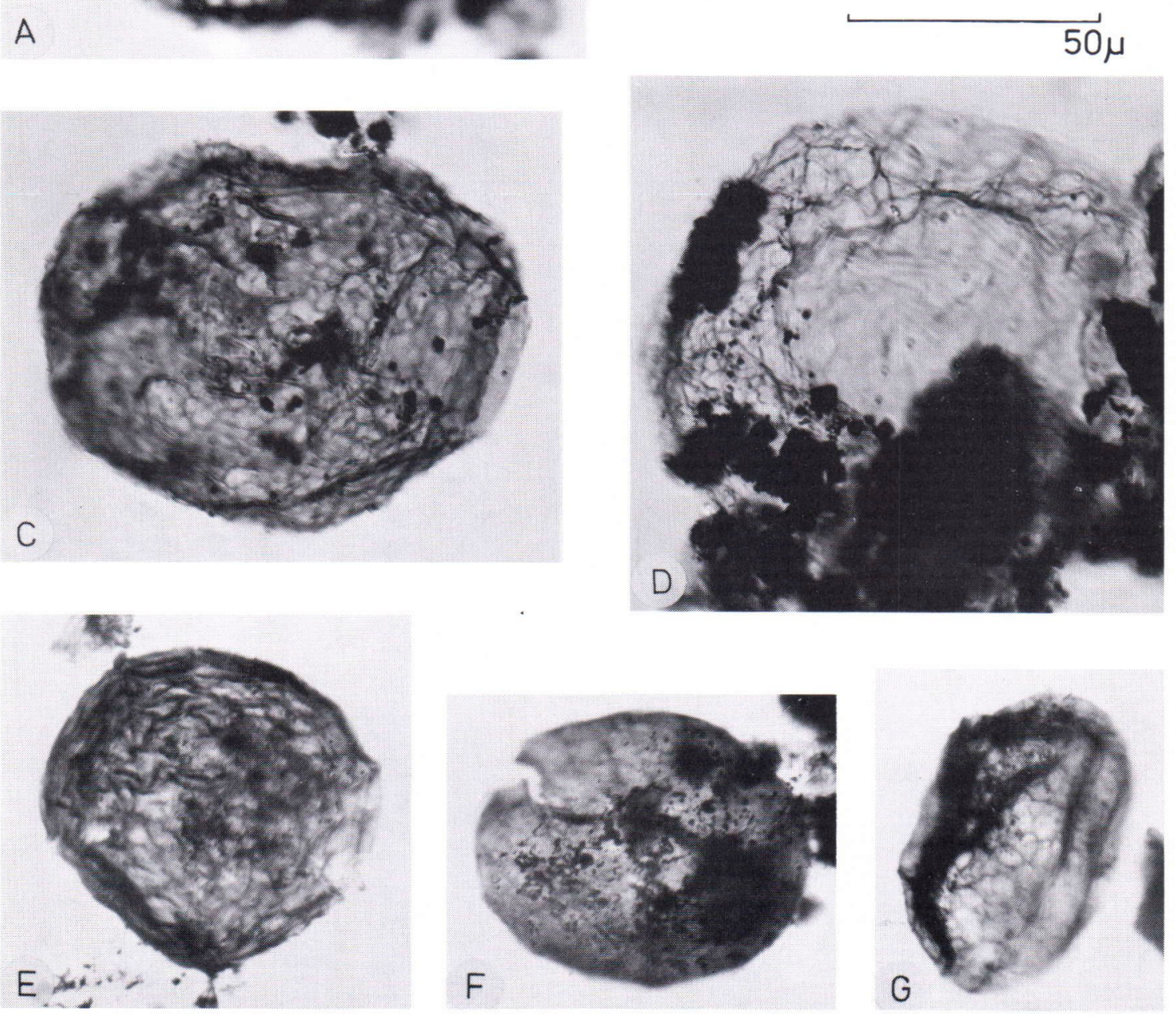


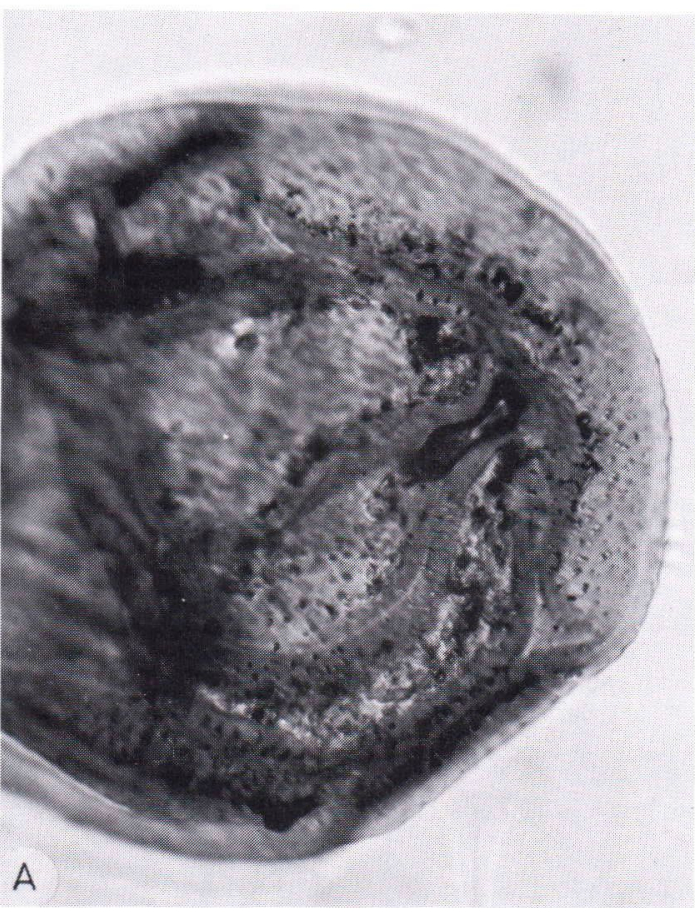

$50 \mu$
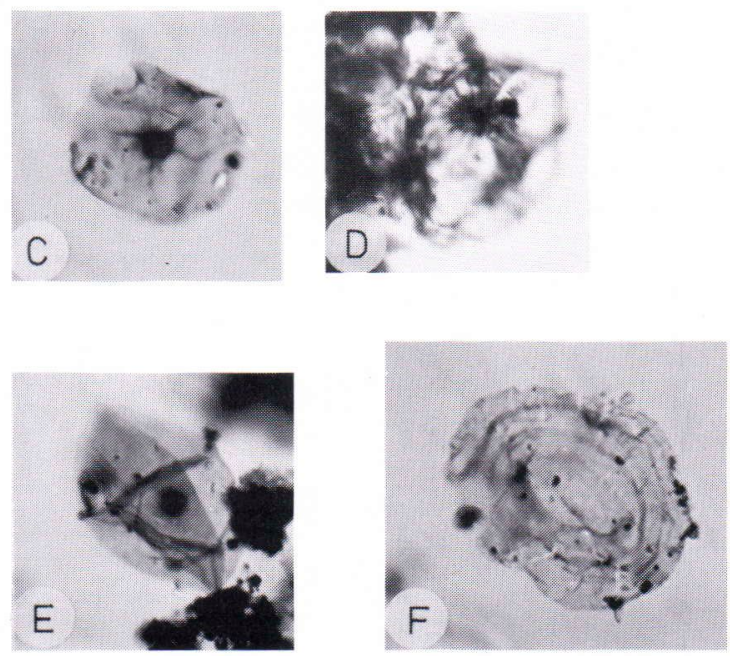
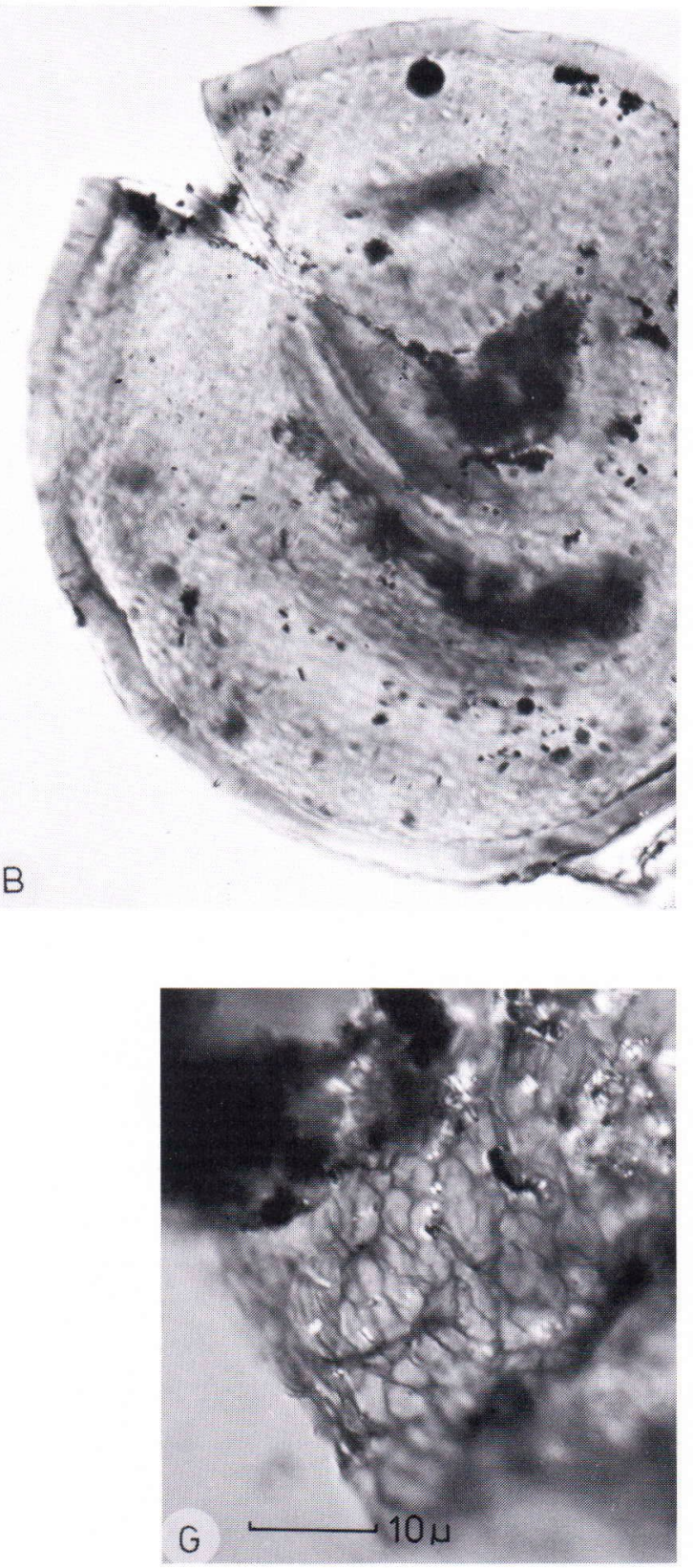

Fig. 8. A. Tasmanites bobrowskii, B. T. piritaensis, C, D. Archaeodiscina umbonulata, E. A. sp., F. acritarch type at a depth of 299.05 m., G. detail of Dictyotidium bottnicum.

Fig. 7. Dictyotidium bottnicum n. sp. 
H o l o t y p e: Fig. 7A, Geological Survey of Finland slide No. 315, Söderfjärden drilling, depth $299.05 \mathrm{~m}$, Lower Cambrian formation.

Remarks: Dictyotidium genus of the acritarchs was described by Eisenack in 1955 from the Silurian deposits in the Baltic area. The Stictosphaeridium brayense described from the Irish Cambrian (Gardiner \& Vanguestaine 1971) corresponds to the type characterised by a similar polygonal surface pattern. It is, however, smaller and has a larger mesh than the species at Söderfjärden. Vidal (1981) has founded the species Dictyotidium birvetense Paškev. from Hardgeberg (Holmia A) and the Gislöv formation in Sweden. In the area of the East European Platform the species has been found in the Lontova formation (Volkova et al. 1979, Korkutis 1981). Another Lower Cambrian Dictyotidium species, priscum Kir. et Vol., has also been encountered in the East European Platform (Volkova et al. 1979) and in Denmark in the Holmia A deposit of Grønne Skifre (Vidal 1981).

Archaeodiscina sp. (Fig. $8 \mathrm{E}$ )

A dark spot on the sphere distinguishes the species from the Leiospaeridia genus. The form also resembles the Archaeodiscina umbonulata Volk. but the radial ridges around the spot are lacking. The diameter is about $30 \mu$. Cf. Nucellosphaeridium Timofeev 1966. Very rare at a depth of $261.1 \mathrm{~m}$.

A platy and rounded acritarch type with a concentric ridge pattern was detected at a depth of $299.05 \mathrm{~m}$. Only one individual was encountered (Fig. 8 F).

\section{Comparison of the results with some acritarch types reported from the Lower Cambrian deposits in the Baltic and Scandinavia}

The biostratigraphic division, which was developed from the results of recent acritarch studies on the Baltic and Scandinavian
Lower Cambrian deposits and from fossil comparisons, is applied in the following to date tentatively the Söderfjärden deposit. The stratigraphic distribution of the Lower Cambrian acritarchs in the East European platform and Scandinavia proposed by Vidal (1981a, b) is based on results by Volkova et al. (1979) from the East European Platform and on those applied to Scandinavia from the studies by Vidal. The acritarch table given by Vidal shows that the Lükati formation has the highest number of species in common with the Söderfjärden deposit. The species significant for dating are Archaeodiscina umbonulata, Baltisphaeridium cerinium and Lophosphaeridium tentativum. The presence of the former in the lower part of the Söderfjärden deposit is indisputable down to a depth of $278.05 \mathrm{~m}$. Besides in the East European Platform, the species has been encountered in the Norretorp sandstone in Skåne, which also contains Schmidtiellus mickwitzi (Holmia A), in Mickwitzia sandstone in Västergötland (Holmia A-B) and in the Lingulid sandstone (Holmia B).

Baltisphaeridium cerinium Volk. has also been encountered at various sites in Scandinavia and more often in the Holmia A than the Holmia B horizon (Vidal 1981 b, op cit.). Like Tasmanites bobrowskii, it occurs in Mickwitzia sandstone.

\section{Paleontologic dating of the sedimentary rock of Söderfjärden}

The fossils and microfossils suggest that the sedimentary formation at Söderfjärden, $243.73 \mathrm{~m}$ thick, deposited in the Lower Cambrian during a rather short period. Volborthella tenuis at a depth of $119 \mathrm{~m}$, Mickwitzia monilifera at $237.8 \mathrm{~m}$ and the trilobite of the olenellid group at $278.05 \mathrm{~m}$ are known from the Holmia A stages, which correspond to the Lükati formation. Small changes in the 
acritarchs of the thick sedimentary deposit corroborate the concept that the sedimentation took place during the Lükati stage alone.

Guide fossils typical of the Lontova stage preceding the Lükati were not found among the microfossils of Söderfjärden. In the Eastern Europe platform the following acritarchs are confined to the Lontova formations: Ceratophyton vernicosum Kir. and Dictyotidium birvetense Paškev. (Volkova et al. 1979, Vidal 1981). The deposit of Lower Cambrian shale at Finngrundet, which also contains fossils of Volborthella tenuis and Mickwitzia monilifera (Thorslund and Axberg 1979), bears the closest resemblance to the Söderfjärden deposit. Acritarch studies demonstrate that the majority of the dyke fillings in the sandstones in Aland were formed in the Lower Cambrian, and that at least some of the Lower Cambrian dykes in Aland are contemporaneous with the Söderfjärden shale (Bergman, Tynni and Winterhalter 1982). Common acritarch species include Archaeodiscina umbonulata, (Fig. $8 \mathrm{C}$ D) Baltisphaeridium type, Cymatiosphaera solfensis, Lophosphaeridium sp. and Tasmanites bobrowskii (Fig. $8 \mathrm{~A}$ ).

The Lower Cambrian sediments discovered in the Northern Baltic were deposited during the Lower Cambrian transgression, which probably culminated during the Lükati stage. It corresponds to the transgression of $\mathrm{Vol}$ borthella tenuis time (Öpik 1956, Martinsson 1974).

\section{References}

Ahlberg, P., 1979. Early Cambrian trilobites from Mount Luopakte northern Sweden. Sveriges Geol. Unders. Ser. C Nr 765, Årsbok 73 Nr 6, $12 \mathrm{p}$.

Bergman, L., Tynni, R. and Winterhalter, B., 1982. Paleozoic sediments in the rapakivi area of the Åland Islands. Geol. Surv. Finland, Bull. 317, $1-132$.

Dean, W. T. and Martin, F., 1978. Lower Ordovician acritarchs and trilobites from Bell Island, eastern Newfoundland. Geol. Surv. Canada Bull. $284,35 \mathrm{p}$.

Gardiner, P. R. R. and Vanguestaine, M., 1971. Cambrian and Ordovician Microfossils from South-East Ireland and their implications. Geol. Surv. Ireland Bull. Vol. 1, 163-210. 2 pls.

Gavelin, A., 1909. Om underkambriska sandstensgångar vid västra stranden av Vänern. Sveriges Geol. Unders. Ser. C, 217. 17 p.

Högbom, A. G. and Ahlström, N. G., 1924. Über die subkambrische Landfläche am Fusse vom Kinnekulle. Bull. Geol. Inst. Univ. Uppsala 19, $55-88$.

Holm, G., 1901. Kinnekulles berggrund in Holm, G. and Munthe. H. 1901. Kinnekulle, dess geologi och den tekniska användingen af dess bergarter. Sveriges Geol. Unders. Ser. C, 172, 76 p.
Jankauskas, T. V. \& Posti, E., 1976. New Cambrian acritarchs from the East Baltic area (English summary). Eesti NSV Tead. Akad. Toim. Keemia-Geol. 25, 145-151.

Korkutis, V., 1981. Late Precambrian and Early Cambrian in the East European Platform. Precambrian Research, 15, 75-94.

Korkutis, V. A., Lapinskas, P. P. and Lashkov, E. M., 1972. Lithologiya i fatsii neftenosnych otlozhenii nizhnego paleozoya Yuzhnoi Pribaltiki. Nedra, Moscow, pp. 1-179.

Laurén, L., Lehtovaara, J., Boström, R. and Tynni, $R ., 1978$. On the geology and the Cambrian sediments of the circular depression at Söderfjärden, western Finland. Geol. Surv. Finland, Bull. 297, 1-81.

Martinsson, A., 1974. The Cambrian of Norden. Pp. 185-283 in Cambrian of the British Isles, Norden and Spitsbergen, ed. by C. H. Holland, Wiley \& Sons. London.

Mens, K. A. \& Pirrus, E. A., 1977. Stratotipičeskie razrezy kembrija Estonii. Akad. Nauk Estonskoi SSR, Inst. Geol. Tallinn, 1-68.

Öpik, A. A., 1956. Cambrian (Lower Cambrian) of Estonia. 20th Int. Geol. Congr. Mexico. El sistema Cambrico, su paleogeografia y el problema de su bese. T. 1, 97-126. 
Poulsen, C., 1932. The Lower Cambrian faunas of East Greenland. Medd. Grønland 87, (6), 66 p., 14 pls.

Skjeseth, S., 1963. Contributions to the geology of the Mjøsa districts and the classical sparagmite area in southern Norway. Norges Geol. Unders. 220 ,

Thorslund, P. \& Axberg, S., 1979. Geology of the southern Bothnian Sea. Part I. Bull. Geol. Inst. Univ. Uppsala, N. S. 8, 35-62.

Thorslund, P. \& Westergård, A. H., 1938. Deep boring through the Cambro-Silurian at File Haidar, Gotland. Sveriges Geol. Unders. Ser. C, 415.

Timofeev, B. V., 1966. Mikropaleofitologiceskoja charakteristika dreonich svit. Izd. "Nauka», Leningrad, $147 \mathrm{p}, 89 \mathrm{pl}$.

Tynni, R., 1978. in Laurén et al., 1978.

Vidal, G., 1981 a. Lower Cambrian acritarch stratigraphy in Scandinavia. Geol. För. Stockholm Förh. 103, 183-192.

Vidal, G., 1981 b. Micropalaeontology and biostratigraphy of the Lower Cambrian sequence in Scandinavia. Taylor, M. E. (ed.): Short Papers for the Second Intern. Symp. Cambrian system 1981. U. S. Geol. Surv. Open-File Rep. 81-743, pp. $232-235$.

Volkova, N. A., Gnilovskaya, M. B., Lendzion, K., Kiryanov, V.V., Palij, V.M., Pashchkyavichene, L. T., Piskun, L. V., Posti, E., Rozanov, A. Yu, Urbanek, A., Fedonkin, M. A., \& Yankauskas, T. V., 1979. Upper Precambrian and Cambrian paleontology of East-European Platform. Nauka, Moscow, Akad. Nauk. SSSR, Geolog. Inst. $210 \mathrm{p}$.

Wazynska, H., 1967. Wstepne badania mikroflorystyczne osadów sinianu i kambru z obszaru Biatowiezy. Kvartalnik Geologiezny I., 11, $10-20$.

Westergård, A. H., 1940. Nya djupborrningar genom äldsta ordovicium och kambrium i Östergötland och Närke. Sveriges Geol. Unders. Ser C, 437.

Wiman, C., 1903. Studien über das Nordbaltische Silurgebiet. I. Olenellussandstein, Obolussandstein und Ceratopygeschiefer. Bull. Geol. Inst. Univ. Upsala. 6, 12-76.

Manuscript received, April 26, 1982 